University of Nebraska - Lincoln

DigitalCommons@University of Nebraska - Lincoln

USDA National Wildlife Research Center - Staff Publications
U.S. Department of Agriculture: Animal and Plant Health Inspection Service

October 2007

\title{
Determination of Sulfadimethoxine Residues in Skunk Serum by HPLC
}

Thomas M. Primus

United States Department of Agriculture/Animal Plant Health Inspection Service/Wildlife Services/ National Wildlife Research Center

Susan M. Jojola United States Department of Agriculture/Animal Plant Health Inspection Service/Wildlife Services/ National Wildlife Research Center

Stacie J. Robinson United States Department of Agriculture/Animal Plant Health Inspection Service/Wildlife Services/ National Wildlife Research Center

John J. Johnston United States Department of Agriculture/Animal Plant Health Inspection Service/Wildlife Services/ National Wildlife Research Center

Follow this and additional works at: https://digitalcommons.unl.edu/icwdm_usdanwrc

Part of the Environmental Sciences Commons

Primus, Thomas M.; Jojola, Susan M.; Robinson, Stacie J.; and Johnston, John J., "Determination of Sulfadimethoxine Residues in Skunk Serum by HPLC" (2007). USDA National Wildlife Research Center Staff Publications. 717.

https://digitalcommons.unl.edu/icwdm_usdanwrc/717

This Article is brought to you for free and open access by the U.S. Department of Agriculture: Animal and Plant Health Inspection Service at DigitalCommons@University of Nebraska - Lincoln. It has been accepted for inclusion in USDA National Wildlife Research Center - Staff Publications by an authorized administrator of DigitalCommons@University of Nebraska - Lincoln. 


\title{
Determination of Sulfadimethoxine Residues in Skunk Serum by HPLC
}

\author{
Thomas M. Primus, Susan M. Jojola, Stacie J. Robinson, and \\ John J. Johnston \\ United States Department of Agriculture/Aninal Plant Health Inspection \\ Service/Wildlife Services/National Wildlife Research Center, Fort \\ Collins, Colorado
}

\begin{abstract}
Sulfadimethoxine (SDM) was extracted from skunk serum and isolated by reversed-phase high performance liquid chromatography. SDM was detected by ultra-violet absorbance at $270 \mathrm{~nm}$ and quantified by comparison to an external calibration standard. Recovery data were determined by analyzing SDM fortified control serum. The overall mean recovery with relative standard deviations of SDM in fortified skunk serum samples was $99 \pm 7 \%$. The recovery for $0.38,5.2$, and $14.2 \mu \mathrm{g} / \mathrm{mL}$ SDM was $96.0 \pm 7.5 \%, 102 \pm 6.1 \%$, and $97.3 \pm 5.1 \%$, respectively. The method limit of detection for SDM in skunk serum ranged from 0.032 to $0.057 \mu \mathrm{g} / \mathrm{mL}$ SDM with a mean value of $0.040 \mu \mathrm{g} / \mathrm{mL}$ SDM. The method reported is much simpler and equally efficient as previous methods developed for the determination of SDM residues in serum.
\end{abstract}

Keywords: Sulfadimethoxine, High performance liquid chromatography, Serum, Skunk

\section{INTRODUCTION}

The large percentage of rabies cases reported in wildlife occurs in skunks (Mephitis mephitis). ${ }^{[1]}$ A functioning deliverable oral bait vaccination of skunks for rabies control is currently in the development stage. ${ }^{[2]}$ While an oral rabies vaccine is being developed, an efficient bait and sachet were

This article not subject to U.S. copyright law.

Address correspondence to Thomas M. Primus, United States Department of Agriculture/Aninal Plant Health Inspection Service/Wildlife Services/National Wildlife Research Center, 4101 LaPorte Ave., Fort Collins, Colorado 80521. E-mail: thomas.m.primus@aphis.usda.gov 
tested. To test bait ingestion by skunks a biomarker was used in place of a vaccine. Sulfadimethoxine (SDM) dissolved in deionized water was used as a mock vaccine in the sachets. Sulfadimethoxine is a sulfonamide, which is a bacteriostatic and has antibacterial properties when potentiated with trimethoprim. Sulfadimethoxine has been demonstrated clinically or in the laboratory to be effective against a variety of organisms, such as streptococci, klebsiella, proteus, shigella, staphylococci, escherichia, and salmonella. ${ }^{[3]}$ Sulfadimethoxine treatment has been shown to reduce the levels of these organisms in respiratory, genitourinary, enteric, and soft tissue infections of dogs and cats. Additionally, sulfadimethoxine has been demonstrated to be a promising biomarker to monitor bait consumption with dogs, ${ }^{[4]}$ raccoons, ${ }^{[5]}$ and badgers. ${ }^{[6]}$

Most methods for the analysis of sulfadimethoxine have a sample cleanup step following the extraction procedure. Most cleanup steps are accomplished by liquid-liquid extraction, solid-phase extraction columns, or on-line columns prior to the analytical column in the HPLC analysis. ${ }^{[7-10]}$ Others have used liquid chromatography/mass spectrometry (LC/MS) to possibly avoid sample extract cleanup. ${ }^{[11-12]}$ Unfortunately, LC/MS is not a widely available technique for routine analysis. There are also enzyme linked immunosorbent assay (ELISA) test methods to determine sulfadimethoxine in some matrices, which have become commercially available. ${ }^{[13-14]}$

The ELISA method was providing inconsistent results with calibration standards and skunk serum samples, therefore, the Analytical Chemistry Project (ACP) at the National Wildlife Research Center (NWRC) was asked to develop a simple and efficient method for the determination of sulfadimethoxine in skunk serum. The objective of the Analytical Chemistry Project was to develop a high throughput method without a cleanup step for the analysis of SDM in skunk sera. Bait acceptance and preferences could be determined by applying this method to quantify SDM residues in skunk serum after animals were offered sachets filled with mock vaccine (aqueous SDM solutions).

\section{EXPERIMENTAL}

\section{Sample Collection}

Whole blood samples were collected from skunks 1 to 4 days post exposure to sachets filled with an $80 \mathrm{mg} \mathrm{SDM} / \mathrm{mL}$ aqueous solution (mock vaccine) of the sodium salt of sulfadimethoxine. Blood samples were collected and approximately $500 \mu \mathrm{L}$ of whole blood was centrifuged (Eppendorf Micro Centrifuge 5415C) at a relative centrifugal force of $12,600 \times \mathrm{g}$ for $10 \mathrm{~min}$. A 200 to $400 \mu \mathrm{L}$ portion of the serum was transferred to a separate vial and stored in a freezer at $-12^{\circ} \mathrm{C}$ until assayed. 


\section{Reagents}

Acetontrile was liquid chromatography grade (Fischer Scientific, Denver, $\mathrm{CO}$ ). Deionized water was purified using an in-house reversed osmosis water purification system. Technical grade potassium dihydrogen phosphate (Fischer Scientific, Denver, CO) was used to prepare the aqueous $0.025 \mathrm{M}$ phosphate buffer solution. The buffer solution was adjusted to a $\mathrm{pH}$ of 5.0 with a $4 \mathrm{~N}$ phosphoric acid solution.

Technical grade sulfadimethoxine, sodium salt (99\%) was obtained from Sigma-Aldrich (St. Louis, MO). A concentrated stock standard of sulfadimethoxine was prepared by first drying the technical grade compound for 4 hours at $110^{\circ} \mathrm{C}$, then dissolving $5.000 \mathrm{mg}$ in $10.0 \mathrm{~mL}$ of methanol. Working standards, ranging in concentration from 0.100 to $10.0 \mu \mathrm{g} / \mathrm{mL}$, were prepared by dilution of stock solutions with mobile phase. All standard solutions were stored in the dark at $23^{\circ} \mathrm{C}$.

\section{Response Linearity}

Two sets of six sulfamethoxine standard solutions were prepared ranging from 0.100 to $9.93 \mu \mathrm{g} / \mathrm{mL}$. Data were collected from duplicate injections of each solution and a plot was constructed of analyte peak response (y-axis) vs sulfadimethoxine concentration (x-axis).

\section{Sample Preparation}

A $100 \mu \mathrm{L}$ aliquot of each sample was transferred into a $1.5 \mathrm{~mL}$ plastic Eppendorf microcentrifuge tube. To each sample, a $100 \mu \mathrm{L}$ portion of phosphate buffer was added, followed by $200 \mu \mathrm{L}$ of acetontrile. The acetonitrile is significant in that most of the blood proteins remaining in the serum are denatured and precipitate out of the sample solution. Each sample vial was vortex mixed and placed in an ultracentrifuge (Eppendorf Micro Centrifuge 5415C) at a relative centrifugal force of $12,600 \times \mathrm{g}$ for 10 minutes. The extract was transferred to a sample vial with a $0.350 \mathrm{~mL}$ insert (Supelco, Bellefonte, PA), capped, and analyzed by high performance liquid chromatography (HPLC).

\section{High Performance Liquid Chromatography}

The HPLC system consisted of a Hewlett-Packard 1090 liquid chromatograph (Palo Alto, CA) equipped with a diode array multiple wavelength detector (Table 1). The mobile phase was prepared by mixing $600 \mathrm{~mL}$ of $20 \mathrm{mM}$ dihydrogen phosphate buffer $(\mathrm{pH}=5.00)$ and $400 \mathrm{~mL}$ of acetonitrile. The 
Table 1. HPLC parameters for the analyses of skunk serum extracts

\begin{tabular}{ll}
\hline Parameter & \multicolumn{1}{c}{ Conditions } \\
\hline Mobile phase & $60: 40$ Water w/20 $\mathrm{mM} \mathrm{KH}_{2} \mathrm{PO}_{4}$ :Acetonitrile \\
Column cleaner & $6: 4 \mathrm{Water}$ Acetonitrile \\
Flow rate & $1.0 \mathrm{~mL} / \mathrm{min}$ \\
Injection volume & $25 \mu \mathrm{L}$ \\
Column & Phenomenex ODS $3(\mathrm{C} 18), 5 \mu \mathrm{m}, 250 \mathrm{~mm} \times 4.6 \mathrm{~mm}$ i.d. \\
& $\quad$ or equivalent (use guard column containing identical \\
& HPLC packing) \\
Column temperature & $35^{\circ} \mathrm{C}$ \\
Detector & UV @ 270 nm \\
Run time & 15 minutes \\
\hline
\end{tabular}

mobile phase was degassed by sparging with helium. At the end of each set (28 samples per set) of analyses, the column was washed with a mixture of $6: 4(\mathrm{v} / \mathrm{v})$ water:acetonitrile for 40 minutes.

\section{Quality Control Samples and Fortification of Controls}

Pretreatment samples from two animals were screened and used to prepare quality control samples. Control samples were fortified at $0.38,5.2$, and $14.2 \mathrm{mg} / \mathrm{kg}$ sulfadimethoxine with aliquots of fortification standards of sulfadimethoxine in methanol. Each $100 \mu \mathrm{L}$ portion of control serum was fortified with $5 \mu \mathrm{L}$ of fortification standards at $8.0,110$, and $300 \mu \mathrm{g} / \mathrm{mL}$. The aliquot of $5 \mu \mathrm{L}$ was used to minimize the amount of protein being denatured by methanol. The quality control samples were then assayed with the method described previously.

\section{RESULTS AND DISCUSSION}

\section{Response Linearity}

A linear regression was performed on the data set and produced an $r^{2}=0.9997$. The plot of $\log$ (peak response) vs log (sulfadimethoxine concentration) produced a slope of 0.99140 and an $r^{2}=0.9997$. The average response factor over the range of the calibration curve produced a coefficient of variation of $2.8 \%$. A linear and proportional relationship existed between chromatographic peak response and sulfadimethoxine concentration. Therefore, a single point calibration was used to calculate the concentration of sulfadimethoxine in the sample extracts. 


\section{Method Limit of Detection}

The method limit of detection (MLOD) was calculated as the concentration of sulfadimethoxine required in the sample to generate a signal equal to 3 times the baseline noise (peak to peak) observed in the chromatogram of the control extract. The MLOD was estimated from the chromatographic response in height of a control serum extract and an extract from a control serum sample fortified at $0.38 \mu \mathrm{g} / \mathrm{g}$. The mean MLOD for skunk serum samples was $0.040 \mu \mathrm{g} / \mathrm{mL}$. For the chromatographic parameters chosen, the retention time of sulfadimethoxine was approximately 6.3 minutes as shown in Figure 1. No significant chromatographic response was noted at the retention time of sulfamethoxine in the chromatogram of the control tissue extract (Figure 2).

\section{Sulfadimethoxine Recoveries from Fortified Control Serum and Residues Detected}

Control serum collected from skunks not exposed to sulfadimethoxine was fortified at $0.38(\mathrm{n}=6), 5.2(\mathrm{n}=6)$, or $14.2 \mu \mathrm{g} / \mathrm{mL}(\mathrm{n}=3)$ and produced recoveries of $96.0 \pm 7.5 \%, 102 \pm 6.1 \%$, and $97.3 \pm 5.1 \%$, respectively. The overall mean recovery of sulfadimethoxine fortified control skunk serum $(\mathrm{n}=15)$ was $99 \pm 7 \%$. Sulfadimethoxine residues were calculated as the average of duplicate analyses of samples, when greater than $200 \mu \mathrm{L}$ of serum was available.

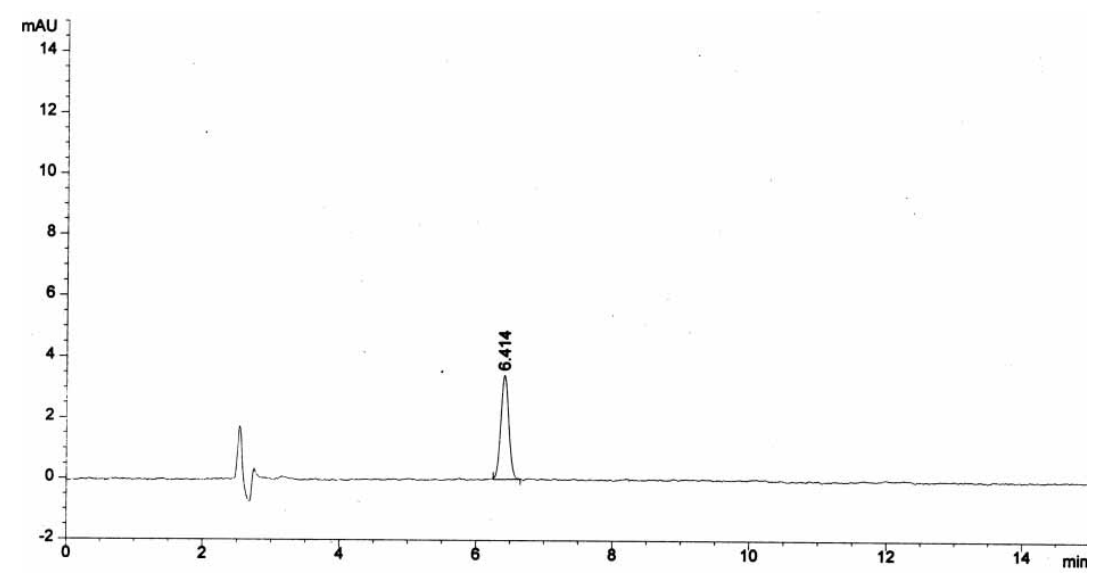

Figure 1. Chromatogram of a $0.60 \mu \mathrm{g} / \mathrm{mL}$ sulfadimethoxine standard detected at $270 \mathrm{~nm}$. 


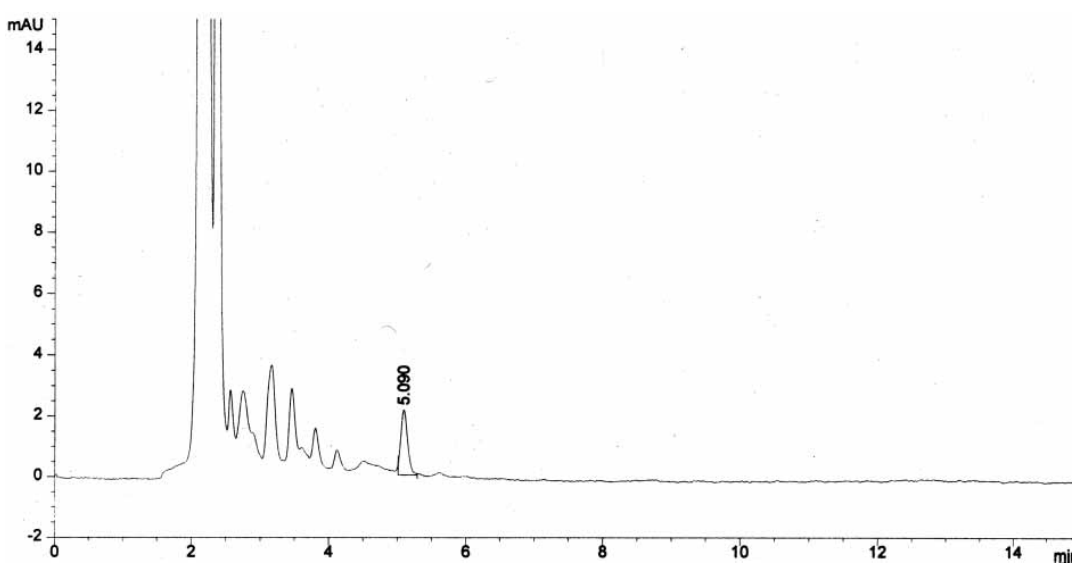

Figure 2. Chromatogram of a control skunk serum extract detected at $270 \mathrm{~nm}$.

Sulfadimethoxine residues in skunk serum of the samples analyzed ranged from $<$ MLOD to $28.7 \mu \mathrm{g} / \mathrm{mL}$. A chromatogram of a skunk serum extract collected day 1 post exposure is shown in Figure 3. The sulfadimethoxine residues were observed in a few animals 4 days post exposure, as shown in Figure 4 , this skunk serum contained $0.050 \mu \mathrm{g} / \mathrm{mL}$ SDM. Very few animals were observed to have detectable levels of sulfadimethoxine after 4 days. The concentration of sulfadimethoxine on day 1 post exposure ranged from 1.1 to $28.7 \mu \mathrm{g} / \mathrm{mL}$ with a mean of $7.4 \mu \mathrm{g} / \mathrm{mL}$.

The addition of acetonitrile to the serum denatured a large portion of the blood proteins, followed by the centrifuge step which produced a sample free

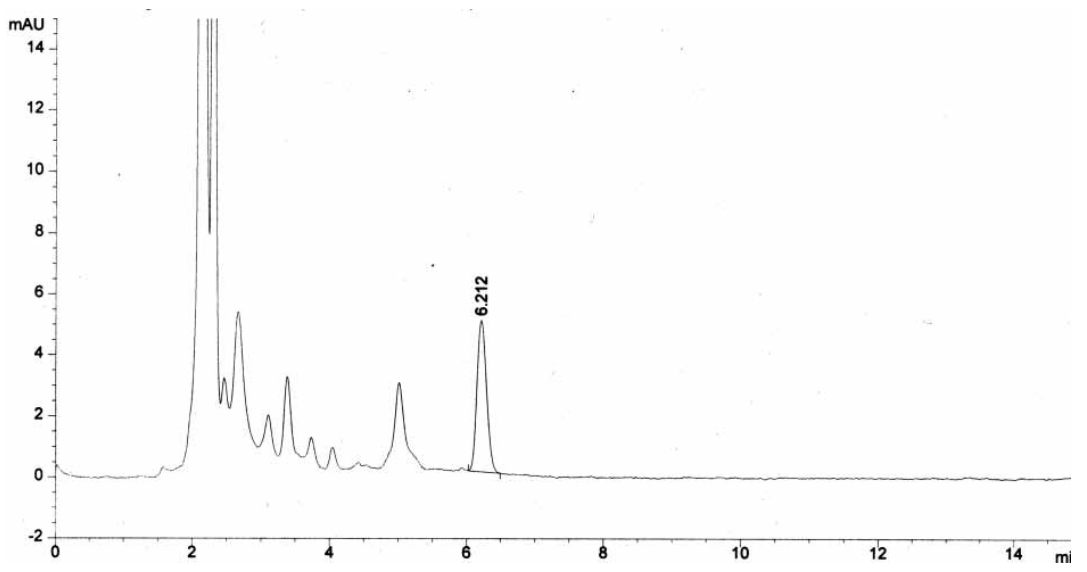

Figure 3. Chromatogram of a skunk serum extract detected at $270 \mathrm{~nm}$, which contains $3.84 \mu \mathrm{g} / \mathrm{mL}$ sulfadimethoxine. 


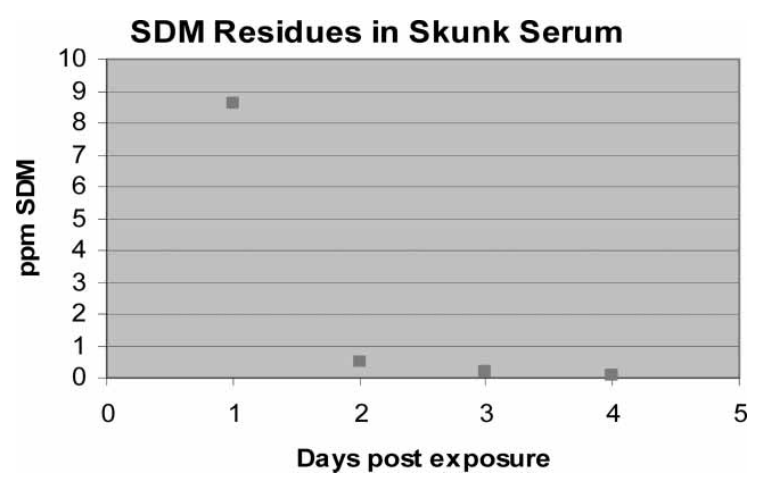

Figure 4. A representative set of sulfadimethoxine residues from a skunk exposed to sachet containing a solution of the biomarker.

of interferences at the retention time of sulfadimethoxine (Figure 2 and Figure 3). Therefore, a cleanup step was not required and, thus, the method proved to be extremely simple and efficient as over 120 samples were analyzed in less than two weeks.

\section{REFERENCES}

1. Krebs, J.W.; Rupprecht, C.E.; Childs, J.E. Rabies surveillance in the United States during 1999. J. Am. Vet. Med. Assoc. 2000, 7 (12), 1799-1811.

2. Jojola, S.M.; Robinson, S.J.; VerCauteren, K.C. Oral rabies vaccine (ORV) bait uptake by striped skunks: Preliminary results, Proc. 21st Vertebr. Pest Conf., 2004, pp. 190-193.

3. Stowe CM: The sulfonamides. In Veterinary Pharmacology and Therapeutics; Jones, L.M, ed. Iowa University Press: Ames, IA, 1965; 457 pp.

4. Matter, H.C.; Schumacher, C.L.; Kharmachi, H.; Hammami, S.; Tlatli, A.; Jemli, L.; Mrabet, L.; Meslin, F.X.; Aubert, M.F.A.; Neuenschwander, B.E.; Hicheri, K.E. Field evaluation of two bait delivery systems for the oral immunization of dogs against rabies in Tunisia. Vaccine 1998, 16, 657-665.

5. Hanlon, C.A.; Buchanan, J.R.; Nelson, E.; Niu, D.; Diehl, D.; Rupprecht, C.E. A vacciniation vectored rabies vaccine field trial: Ante- and post-mortem biomarkers. Rev. Scientifique et Tech. 1993, 12, 99-107.

6. Southey, A.K.; Sleeman, D.P.; Gormley, E. Sulfadiomethoxine and rhodamine B as oral biomarkers for European badgers (Meles meles). J. Wildl. Dis. 2002, 38 (2), $378-384$.

7. Takeda, N.; Akiyama, Y. Rapid determination of sulphonamides in milk using liquid chromatographic separation and fluorescamine derivatization. J Chromatogr. 1992, 21 (1), 31-607.

8. Smedley, M.D. Liquid chromatographic determination of multiple sulfonamide residues in bovine milk: collaborative study. J. AOAC Int. 1994, 77 (5), 1112-22.

9. Walker, C.C.; Thune, R.L.; Barker, S.A. Plasma/muscle ratios of sulfadimethoxine residues in channel catfish (Ictalurus punctatus). J. Vet. Pharmacol. Ther. 1995, 18 (4), 306-10. 
10. Furusawa, N.; Kishida, K. High-performance liquid chromatographic procedure for routine residue monitoring of seven sulfonamides in milk. Fresenius J. Anal. Chem. 2001, 371 (7), 1031-3.

11. Clark, S.B.; Turnipseed, S.B.; Madson, M.R.; Hurlbut, J.A.; Kuck, L.R.; Sofos, J.N. Confirmation of sulfamethazine, sulfathiazole, and sulfadimethoxine residues in condensed milk and soft-cheese products by liquid chromatography/ tandem mass spectrometry. J. AOAC Int. 2005, 88 (3), 736-43.

12. Diaz-Cruz, M.S.; Lopez de Alda, M.A.; Barcelo, D. Determination of antimicrobials in sludge from infiltration basins at two artificial recharge plants by pressurized liquid extraction-liquid chromatography-tandem mass spectrometry. J. Chromatogr. A 2006, 1130 (1), 72-82.

13. Muldoon, M.T.; Holtzapple, C.K.; Deshpande, S.S.; Beier, R.C.; Stanker, L.H. Development of a monoclonal antibody-based cELISA for the analysis of sulfadimethoxine. 1. Development and characterization of monoclonal antibodies and molecular modeling studies of antibody recognition. J Agric. Food Chem. 2000, 48 (2), 537-44.

14. Walker, C.C.; Barker, S.A. Extraction and enzyme immunoassay of sulfadimethoxine residues in channel catfish (Ictalurus punctatus) muscle. J. AOAC Int. 1994, 77 (4), 908-16.

Received March 7, 2007

Accepted April 17, 2007

Manuscript 6062 